\title{
Waris Banci Menurut Kompilasi Hukum Islam
}

\author{
Ahmadin \\ STKIP Taman Siswa Bima, \\ 1madin_uni15@yahoo.co.id, \\ ${ }^{*}$ Corresponding Author
}

Artikel Info

Tanggal Publikasi

2019-06-30

\section{$\underline{\text { Kata Kunci }}$}

Waris

Banci dan Kompilasi Hukum Islam

\begin{abstract}
Abstrak
Warisan adalah perkara yang penting bagi kehidupan Kita. Tidak hanya untuk diri pribadi, melainkan juga untuk anak cucu kita akan kelak. Meskipun penting, seringkali perihal warisan ini menimbulkan berbagai permasalahan. Tidak heran, banyak juga orang yang putus tali persaudaraannya karena hak warisan. Permasalahan utamanya biasanya karena perbedaan pendapat mengenai kesetaraan dan keadilan. Berkaitan dengan pelaksanaan hukum kewarisan masyarakat Bima tersebut adalah seorang ahli waris yang posisinya yang digantikan berhak mendapat harta warisan baik dari garis keturunan laki-laki maupun dari garis keturunan perempuan dan seorang ahli waris berhak menerima harta warisan untuk dimiliki secara pribadi ataupun secara keluarga sesuai dengan bagian yang telah ditetapkan. Sebagaimana kekerabatan masyarakat Bima yang menarik keturunan dari garis ayah dan garis ibu. Ahli waris pada masyarakat Bima, baik laki-laki maupun perempuan dapat menerima hak kewarisan baik dari garis ayah maupun ibunya. Dan harta warisan yang sudah didapat, dapat dimiliki dan dikuasai oleh ahli waris dari garis ayah atau ibunya yang meninggal tersebut.
\end{abstract}

\section{PENDAHULUAN}

Hukum kewarisan Islam merupakan persoalan yang sangat penting dalam agama Islam sebab hukum ini tercermin langsung dari teks-teks suci yang telah diakui keberadaannya dan masalah yang tidak bisa di pungkiri keberadaannya adalah representasi dalam teks yang sangat rinci, sistematis, kongkrit dan realistis. Kerincian uraian teks tentang kewarisan sampai pada diri para ulama bahwa kewarisan Islam tidak dapat dirubah dan menolak untuk dirubah. Oleh karenanya Warisan adalah perkara yang penting bagi kehidupan Kita. Tidak hanya untuk diri pribadi, melainkan juga untuk anak cucu kita akan kelak. Meskipun penting, seringkali perihal warisan ini menimbulkan berbagai permasalahan. Tidak heran, banyak juga orang yang putus tali persaudaraannya karena hak warisan. Permasalahan utamanya biasanya karena perbedaan pendapat mengenai kesetaraan dan keadilan.

Dalam peraturan dan kemudian perhitungannya cukup rumit. Kita perlu memikirkannya dari sekarang dan berusaha tidak mencoba untuk menomorduakan permasalahan hak waris ini. Dikhawatirkan perihal warisan ini menjadi permasalahan besar yang muncul di masa depan. Untuk itu, kita perlu mempelajari hukum waris di Indonesia dan Kita pun dituntut untuk memahami dan mengerti. Sehingga, saat terjadi pembagian bersama-sama keluarga akan mencapai musyawarah dan mufakat juga tidak adanya perselisihan kemudian tidak adanya omongan di belakang. Menurut hukum waris Islam ada tiga syarat agar pewarisan dinyatakan ada sehingga dapat memberi hak kepada seseorang atau ahli waris untuk menerima warisan:

a. Orang yang mewariskan (pewaris) telah meninggal dunia dan dapat di buktikan secara hukum ia telah meninggal. Sehingga jika ada pembagian atau pemberian harta pada keluarga pada masa pewaris masih hidup, itu tidak termasuk dalam kategori waris tetapi disebut hibah.

b. Orang yang mewarisi (ahli waris) masih hidup pada saat orang yang mewariskan meninggal dunia. 
Orang yang mewariskan dan mewarisi memiliki hubungan keturunan atau kekerabatan, baik pertalian garis lurus ke atas seperti ayah atau kakek dan pertalian lurus ke bawah seperti anak, cucu, dan paman.

Berdasarkan hal tersebut di atas dapat dikatakan bahwa waris banci sah apabila memenuhi dua unsur, pertama dilakukan berdasarkan ajaran islam dan hadist serta pendapat para ulama dan kedua bahwa harus berdasarkan musyawarah dan mufakat bersama keluarga. Kedua hal tersebut harus dipenuhi secara komprehensif, tidak parsial. Artinya, kedua syarat tersebut harus terpenuhi semua dan bukan salah satunya saja yang terpenuhi. Seiring dengan makin berkembanganya kehidupan masyarakat dewasa ini, sering kali kita melihat fenomena yang terjadi dalam kehidupan masyarakat Indonesia seperti adanya pembagian waris yang tidak sesuai dan hanya kehendak masing-masing pewaris. Kemudian adanya pembagian warisan yang ada tersebut, sebenarnya tidak terlepas dari kondisi masyarakat kita yang semakin plural, tidak kuasa membendung hegemoni modernisasi yang cenderung tidak terkontrol, serta berbagai tekanan serta tuntutan hidup yang semakin mahal dewasa ini. Semuanya itu bermuara pada tujuan manusia agar tetapnya lebih baik. Banyaknya jenis pembagian waris sebagaimana tersebut di atas, jelas menimbulkan polemik ditengah kehidupan masyarakat. Banyak pro dan kontra muncul dalam menanggapi masalah ini, tentunya dengan berbagai argumentasi yang dikedepankan masing-masing pihak, mulai dari segi kepastian hukum dari sebuah keluarga hingga masalah keadilan. Masalah kepastian hukum memang menarik untuk dikaji mengingat Indonesia merupakan negara hukum. Tak bisa kita pungkiri pula, bahwa dalam realita yang terjadi, antara kepastian hukum dan keadilan sering kali terjadi disharmoni antara keduanya, karena belum tentu apa yang kita kenal dengan hukum, mencerminkan nilai keadilan, khususnya keadilan dalam perspektif Islam.

Mengingat akhir-akhir ini sering kali diperdebatkan oleh masyarakat masalah waris sampai pada saling membunuh antara keluarga sendiri maka penulis memfokuskan pada hal tersebut, yang terkristalisasi dari judul waris banci menurut kompilasi hukum islam.

Penelitian ini bertujuan untuk: (1) Mengetahui hak waris banci dalam masyarakat; (2) Mengetahui waris banci menurut kompilasi hukum islam.

\section{METODELOGI PENELITIAN}

Penelitian ini menggunakan metode kualitatif bersifat deskriptif bertujuan memberikan gambaran yang jelas, objektif, sistematis, dan cermat mengenai fakta-fakta yang diperoleh dari objek yang ditelaah, yang dalam hal ini adalah terkait waris banci menurut Kompilasi Hukum Islam di Indonesia serta dari konsep keadilan.

\section{Sumber Data}

Berdasar jenis penelitian di atas, sumber data dalam penelitian ini adalah seperti dokumendokumen resmi, buku-buku yang berhubungan dengan objek penelitian, hasil penelitian dalam bentuk laporan, dan peraturan perundang-undangan, data ini dapat dibagi menjadi: a) Sumber data primer; b) sumber data sekunder; c) Sumber data Tersier

\section{Teknik Pengumpulan Data}

Pengumpulan data dalam penelitian ini dilakukan melalui Studi Kepustakaan (library research). Diperoleh melalui penelitian kepustakaan yang bersumber dari Peraturan Perundang-undangan, buku-buku dokumen resmi, publikasi, dan hasil penelitian, khususnya yang terkait waris banci menurut kompilasi hukum islam 


\section{Teknik Analisis Data}

Penelitian ini menggunakan analisis data deskriptif kualitatif, komprehensif, dan lengkap. Analisis kualitatif adalah menguraikan data dalam bentuk kalimat yang teratur, runtun, logis, tidak tumpang tindih dan efektif sehingga memudahkan interpretasi data dan pemahaman hasil analisis. Komprehensif berarti analisis data secara mendalam dari berbagai aspek sesuai dengan lingkup penelitian. Sedangkan lengkap artinya tidak ada bagian yang terlewatkan, kesemuanya sudah masuk dalam analisis.

\section{HASIL DAN PEMBAHASAN}

Dalam literatur figh, kewarisan dikenal dengan istilah al-waris yang maknanya adalah warisan, harta peninggalan, perpindahan hak milik atau perpindahan harta pusaka. Berangkat dari makna dasar ini, Ali as-Sabuni dalam Ahmadin (Jurnal Pendidikan IPS, Vol. 6. No. 1, Januari -Juni 2016) mengatakan dari segi makna yang lebih luas, kata al-irs mengandung arti perpindahan sesuatu dari suatu kaum kepada kaum yang lainnya, baik berupa harta, ilmu, atau kemuliaan. Sudarsono mengatakan kewarisan (al- mawaris) adalah langkah-langkah penerusan dan pengoperan harta peninggalan baik yang berwujud maupun yang tidak berwujud dari seorang pewaris kepada ahli warisnya. Kewarisan Islam adalah aturan yang mengatur pengalihan harta dari seseorang yang meninggal dunia kepada ahli warisnya. Hal ini berarti menentukan siapa-siapa yang menjadi ahli waris, porsi bagian masing-masing ahli waris, menentukan harta peninggalan dan harta warisan bagi orang yang meninggal dimaksud. Dalam pasal 171 (a) Kompilasi Hukum Islam, hukum kewarisan adalah hukum yang mengatur tentang pemindahan hak kepemilikan harta peninggalan (tirkah) pewaris, menentukan siapa-siapa yang berhak menjadi ahli waris dan berapa bagiannya masingmasing.

Hukum waris Islam berlaku bagi masyarakat Indonesia yang beragama Islam dan kemudian juga diatur dalam Pasal 171-214 Kompilasi Hukum Indonesia, yaitu materi hukum Islam yang ditulis dalam 229 pasal. Dalam hukum waris Islam menganut prinsip kewarisan individual bilateral, bukan kolektif maupun mayorat. Dengan demikian pewaris bisa berasal dari pihak bapak atau ibu.

\section{Waris Banci Menurut Kompilasi Hukum Islam}

Pengertian al-khuntsa (banci) dalam bahasa Arab diambil dari kata khanatsa berarti 'lunak' atau 'melunak'. Misalnya, khanatsa wa takhannatsa, yang berarti apabila ucapan atau cara jalan seorang lakilaki menyerupai wanita: lembut dan melenggak-lenggok. Karenanya dalam hadits sahih dikisahkan bahwa Rasulullah saw. bersabda: "Allah SWT melaknat laki-laki yang menyerupai wanita dan wanita yang menyerupai laki-laki."

Adapun makna khanatsa menurut para fuqaha adalah orang yang mempunyai alat kelamin lakilaki dan kelamin wanita (hermaphrodit), atau bahkan tidak mempunyai alat kelamin sama sekali. Keadaan yang kedua ini menurut para fuqaha dinamakan khuntsa musykil, artinya tidak ada kejelasan. Sebab, setiap insan seharusnya mempunyai alat kelamin yang jelas, bila tidak berkelamin laki-laki berarti berkelamin perempuan. Kejelasan jenis kelamin seseorang akan mempertegas status hukumnya sehingga ia berhak menerima harta waris sesuai bagiannya. Oleh karena itu, adanya dua jenis kelamin pada seseorang atau bahkan sama sekali tidak ada disebut sebagai musykil. Keadaan ini membingungkan karena tidak ada kejelasan, kendatipun dalam keadaan tertentu kemusykilan tersebut dapat diatasi, misalnya dengan mencari tahu dari mana ia membuang "air kecil". Bila urinenya keluar dari penis, maka ia divonis sebagai laki-laki dan mendapatkan hak waris sebagaimana kaum laki-laki. Sedangkan jika ia mengeluarkan urine dari vagina, ia divonis sebagai wanita dan memperoleh hak waris sebagai kaum wanita. Namun, bila ia mengeluarkan urine dari kedua alat 
kelaminnya (penis dan vagina) secara berbarengan, maka inilah yang dinyatakan sebagai khuntsa munsykil. Dan ia akan tetap musykil hingga datang masa akil baligh.

Di samping melalui cara tersebut, dapat juga dilakukan dengan cara mengamati pertumbuhan badannya, atau mengenali tanda-tanda khusus yang lazim sebagai pembeda antara laki-laki dengan perempuan. Misalnya, bagaimana cara ia bermimpi dewasa (maksudnya mimpi dengan mengeluarkan air mani), apakah ia tumbuh kumis, apakah tumbuh payudaranya, apakah ia haid atau hamil, dan sebagainya. Bila tanda-tanda tersebut tetap tidak tampak, maka ia divonis sebagai khuntsa musykil.

Dikisahkan bahwa Amir bin adz-Dzarb dikenal sebagai seorang yang bijak pada masa jahiliah. Suatu ketika ia dikunjungi kaumnya yang mengadukan suatu peristiwa, bahwa ada seorang wanita melahirkan anak dengan dua jenis kelamin. Amir kemudian memvonisnya sebagai laki-laki dan perempuan.

Mendengar jawaban yang kurang memuaskan itu orang-orang Arab meninggalkannya, dan tidak menerima vonis tersebut. Amir pun menjadi gelisah dan tidak tidur sepanjang malam karena memikirkannya. Melihat sang majikan gelisah, budak wanita yang dimiliki Amir dan dikenal sangat cerdik menanyakan sebab-sebab yang menggelisahkan majikannya. Akhirnya Amir memberitahukan persoalan tersebut kepada budaknya, dan budak wanita itu berkata: "Cabutlah keputusan tadi, dan vonislah dengan cara melihat dari mana keluar air seninya."

Amir merasa puas dengan gagasan tersebut. Maka dengan segera ia menemui kaumnya untuk mengganti vonis yang telah dijatuhkannya. Ia berkata: "Wahai kaumku, lihatlah jalan keluarnya air seni. Bila keluar dari penis, maka ia sebagai laki-laki; tetapi bila keluar dari vagina, ia dinyatakan sebagai perempuan." Ternyata vonis ini diterima secara aklamasi.

Ketika Islam datang, dikukuhkanlah vonis tersebut. Diriwayatkan dari Ibnu Abbas r.a. bahwa Rasulullah saw. ketika ditanya tentang hak waris seseorang yang dalam keadaan demikian, maka beliau menjawab dengan sabdanya: "Lihatlah dari tempat keluarnya air seni."

Untuk banci menurut pendapat yang paling rajih hak waris yang diberikan kepadanya hendaklah yang paling sedikit di antara dua keadaannya keadaan bila ia sebagai laki-laki dan sebagai wanita. Kemudian untuk sementara sisa harta waris yang menjadi haknya dibekukan sampai statusnya menjadi jelas, atau sampai ada kesepakatan tertentu di antara ahli waris, atau sampai banci itu meninggal hingga bagiannya berpindah kepada ahli warisnya.

Makna pemberian hak banci dengan bagian paling sedikit menurut kalangan fuqaha mawarits mu'amalah bil adhar- yaitu jika banci dinilai sebagai wanita bagiannya lebih sedikit, maka hak waris yang diberikan kepadanya adalah hak waris wanita; dan bila dinilai sebagai laki-laki dan bagiannya ternyata lebih sedikit, maka divonis sebagai laki-laki. Bahkan, bila ternyata dalam keadaan di antara kedua status harus ditiadakan haknya, maka diputuskan bahwa banci tidak mendapatkan hak waris. Bahkan dalam mazhab Imam Syafi'i, bila dalam suatu keadaan salah seorang dari ahli waris gugur haknya dikarenakan adanya banci dalam salah satu dari dua status (yakni sebagai laki-laki atau wanita), maka gugurlah hak warisnya.

\section{Beberapa Contoh Amaliah Hak Waris Banci:}

a. Seseorang wafat dan meninggalkan seorang anak laki-laki, seorang anak perempuan, dan seorang anak banci. Bila anak banci ini dianggap sebagai anak laki-laki, maka pokok masalahnya dari lima (5), sedangkan bila dianggap sebagai wanita maka pokok masalahnya dari empat (4). Kemudian kita menyatukan (al-jami'ah) antara dua masalah, seperti dalam masalah al-munasakhat. Bagian anak laki-laki adalah delapan (8), sedangkan bagian anak perempuan empat (4), dan bagian anak banci lima (5). Sisa harta waris yaitu tiga (3) kita bekukan untuk sementara hingga keadaannya secara nyata telah terbukti. 
b. Seseorang wafat meninggalkan seorang suami, ibu, dan saudara laki-laki banci. Pokok masalahnya dari enam (6) bila banci itu dikategorikan sebagai wanita, kemudian di-'aul-kan menjadi delapan (8). Sedangkan bila sang banci dianggap sebagai laki-laki, maka pokok masalahnya dari enam (6) tanpa harus di- 'aul-kan. Dan al-jami'ah (penyatuan) dari keduanya, menjadilah pokok masalahnya dua puluh empat (24). Sedangkan pembagiannya seperti berikut: suami sembilan (9) bagian, ibu enam (6) bagian, saudara laki-laki banci tiga (3) bagian, dan sisanya kita bekukan.

c. Seseorang wafat dan meninggalkan suami, saudara kandung perempuan, dan saudara laki-laki seayah banci. Maka pembagiannya seperti berikut: Bila banci ini dikategorikan sebagai laki-laki, maka pokok masalahnya dua (2), sedangkan bila dikategorikan sebagai perempuan maka pokok masalahnya dari tujuh (7), dan penyatuan dari keduanya menjadi empat belas (14).

Bagian suami enam (6), saudara kandung perempuan enam (6) bagian, sedangkan yang banci tidak diberikan haknya. Adapun sisanya, yakni dua (2) bagian dibekukan.

Ada tiga pendapat yang masyhur di kalangan ulama mengenai pemberian hak waris kepada banci musykil ini:

a. Mazhab Hanafi berpendapat bahwa hak waris banci adalah yang paling (lebih) sedikit bagiannya di antara keadaannya sebagai laki-laki atau wanita. Dan ini merupakan salah satu pendapat Imam Syafi'i serta pendapat mayoritas sahabat.

b. Mazhab Maliki berpendapat, pemberian hak waris kepada para banci hendaklah tengah-tengah di antara kedua bagiannya. Maksudnya, mula-mula permasalahannya dibuat dalam dua keadaan, kemudian disatukan dan dibagi menjadi dua, maka hasilnya menjadi hak/bagian banci.

c. Mazhab Syafi'i berpendapat, bagian setiap ahli waris dan banci diberikan dalam jumlah yang paling sedikit. Karena pembagian seperti ini lebih meyakinkan bagi tiap-tiap ahli waris. Sedangkan sisanya (dari harta waris yang ada) untuk sementara tidak dibagikan kepada masing-masing ahli waris hingga telah nyata keadaan yang semestinya. Inilah pendapat yang dianggap paling rajih (kuat) di kalangan mazhab Syafi'i.

\section{Kebiasaan Pembagian Hak Waris Masyarakat}

Kekerabatan dan struktur masyarakat Bima adalah beberapa faktor yang mendasari terbentuknya suatu asas - asas hukum kewarisan. Kewarisan pada masyarakat Bima berkaitan erat dengan keluarga, karena kewarisan merupakan peralihan benda atau bukan benda, dari suatu generasi ke generasi berikutnya dalam lingkup keluarga. Secara geografis Kabupaten Bima adalah bagian pulau Sumbawa yang tepatnya Propinsi Nusa Tenggara Barat, secara garis besar Bima mempunyai kultur yang sama dengan Kabupaten Dompu dan Kabupaten lain dalam Propinsi yang sama pada umumnya, akan tetapi mempunyai sub kultur yang berbeda, mengingat bahwa masyarakat Bima yang hampir keseluruhannya adalah muslim yang memiliki tradisi ke-Islaman yang cukup kuat, yang pada akhirnya akan menghasilkan hukum kewarisan Islam yang cukup kuat pula.

Berkaitan dengan pelaksanaan hukum kewarisan masyarakat Bima tersebut adalah seorang ahli waris yang posisinya yang digantikan berhak mendapat harta warisan baik dari garis keturunan lakilaki maupun dari garis keturunan perempuan dan seorang ahli waris berhak menerima harta warisan untuk dimiliki secara pribadi ataupun secara keluarga sesuai dengan bagian yang telah ditetapkan. Sebagaimana kekerabatan masyarakat Bima yang menarik keturunan dari garis ayah dan garis ibu.

Ahli waris pada masyarakat Bima, baik laki-laki maupun perempuan dapat menerima hak kewarisan baik dari garis ayah maupun ibunya. Dan harta warisan yang sudah didapat, dapat dimiliki dan dikuasai oleh ahli waris dari garis ayah atau ibunya yang meninggal tersebut. Ahli waris dalam melaksanakan kewarisan bahwa laki-laki dan perempuan walaupun sama-sama mempunyai hak untuk menerima warisan namun tetap mendapat perbedaan dalam jumlah bagiannya, yaitu untuk laki-laki 
(salemba) atau dalam warisan Islam terdapat bagian setengah (1/2) dari jumlah harta warisan

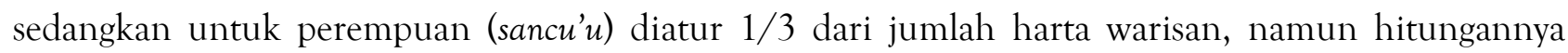
dalam posisi masih hidup semua. perbendaan tersebut merupakan tidak sama dengan aturan hukum waris masyarakat Bima yang menginginkan perbedaan bagian karena dilihat dari segi kreatifitasnya dalam pekerjaan.

Yang dimaksud dalam hal ini adalah untuk laki-laki biasanya membawa barang dengan pikul dan perempuan membawa barang dengan gendongan, pikulan berarti barang yang dibawa lebih banyak sedangkan gendongan lebih kecil dari pada pikulan karena sebagaimana pikulan beban yang dibawa dengan bahu yang biasanya sepasang dan lebih berat dari pada gendongan yang cuman satu wadah. Masyarakat Bima, sancu'u maupun salemba tidak melihat dari apakah laki-laki atau perempuan dalam hal melaksanakan pembagian hukum kewarisan ahli waris tersebut, akan tetapi masyarakat Bima tetap menganggapnya sama dimata pewaris artinya sesuatu yang akan dilaksanakan tersebut tetap mendapatkan sama banyak sepikul dan atau segendong atau disebut duduk sama rendah berdiri sama tinggi.

Makna dari pelaksanaan ini bahwa laki-laki dan perempuan tersebut merupakan hal yang sama dalam mendapatkan banyaknya harta warisan. Ini sebenarnya sangat tidak sesuai dengan aturan hukum kewarisan Islam tetapi itulah sebuah kenyataan dalam hukum pelaksanaan pembagian kewarisan bagi ahli waris pada masyarakat Bima.

Pelaksanaan pembagian hukum waris masyarakat Bima selalu saja dengan mengawali musyawarah terlebih dahulu. Pelaksanaan pembagian harta warisan didasarkan atas kemauan bersama seluruh ahli waris, untuk terciptanya kata mufakat atau kesepakatan diantara mereka. Dalam hal ini tidak ada patokan dalam membagi bagian di bagi sesuai dengan kesepakatan ahli waris. Dimungkinkan salah seorang mendapat bagian lebih banyak dari pada bagian yang lain, tetapi yang mendapat bagian lebih sedikit tidak keberatan, mengingat adanya faktor kondisi ekonomi ahli waris yang mendapat bagian lebih banyak adalah ahli waris yang kurang atau tidak mampu secara ekonomi. Atau ada saat dimana salah seorang ahli waris tidak mengambil bagiannya sama sekali, bagian yang diperoleh ditambahkan kepada ahli waris yang lain karena faktor ekonomi ahli waris tersebut tampa menghapus hak- haknya dalam mewaris, disini sifatnya hanya merelakan bagiannya untuk ditambahkan ke ahli waris yang lain.

\section{KESIMPULAN}

Waris banci dalam hukum hukum Islam dan Kompilasi Hukum Islam adalah perlu adanya kejelasan jenis kelamin seseorang yang akan mempertegas status hukumnya sehingga ia berhak menerima harta waris sesuai bagiannya.

Oleh karena itu, adanya dua jenis kelamin pada seseorang atau bahkan sama sekali tidak ada disebut sebagai musykil. Keadaan ini membingungkan karena tidak ada kejelasan, kendatipun dalam keadaan tertentu kemusykilan tersebut dapat diatasi, misalnya dengan mencari tahu dari mana ia membuang "air kecil". Bila urinenya keluar dari penis, maka ia divonis sebagai laki-laki dan mendapatkan hak waris sebagaimana kaum laki-laki. Sedangkan jika ia mengeluarkan urine dari vagina, ia divonis sebagai wanita dan memperoleh hak waris sebagai kaum wanita. Namun, bila ia mengeluarkan urine dari kedua alat kelaminnya (penis dan vagina) secara berbarengan, maka inilah yang dinyatakan sebagai khuntsa munsykil. Dan ia akan tetap musykil hingga datang masa akil baligh. Sehingga bisa mendapat hak waris yang sesuai dengan porsi ditentukan.

Akan tetapi bila seseorang ahli waris ditemukan dua jenis kelamin maka dia tidak akan diberikan hak waris sesuai dengan kalimat yang sangat tegas makna khanatsa menurut para fuqaha adalah orang yang mempunyai alat kelamin laki-laki dan kelamin wanita (hermaphrodit), atau bahkan tidak mempunyai alat kelamin sama sekali. Keadaan yang kedua ini menurut para fuqaha dinamakan 
khuntsa musykil, artinya tidak ada kejelasan. Sebab, setiap insan seharusnya mempunyai alat kelamin yang jelas, bila tidak berkelamin laki-laki berarti berkelamin perempuan.

Mazhab Imam Syafi'i, bila dalam suatu keadaan salah seorang dari ahli waris gugur haknya dikarenakan adanya banci dalam salah satu dari dua status (yakni sebagai laki-laki atau wanita), maka gugurlah hak warisnya.

\section{Daftar Pustaka}

Abdullah, Abdul Gani, 2004, Peradilan Agama Dalam Pemerintahan Islam di Kesultanan Bima, Lengge, Mataram.

Anshori, Abdul Ghofur, 2002, Kewarisan Islam di Indonesia: Eksistensi $\mathcal{E}$ Adaptabilitas, Ekonisia, Yogyakarta.

...m, 2005, Filsafat Hukum Kewarisan Islam, konsep Kewarisan Bilateral Hazairin, UII Press, Yogyakarta.

Ali, Zainuddin, 2006, Hukum Islam Pengantar Ilmu Hukum di Indonesia, Sinar Grafika, Jakarta.

....., 2008, Pelaksanaan Hukum Waris di Indonesia, Sinar Grafika, Jakarta.

Ash-Shabuni, Muhammad Ali, 1995, Pembagian waris Menurut Islam, Gema Insani Press, Jakarta.

Departemen Agama, 1971, Al-Qur'an dan Terjemahannya, Yayasan Penyelenggara/Penafsir Al-Qur'an, Jakarta. 